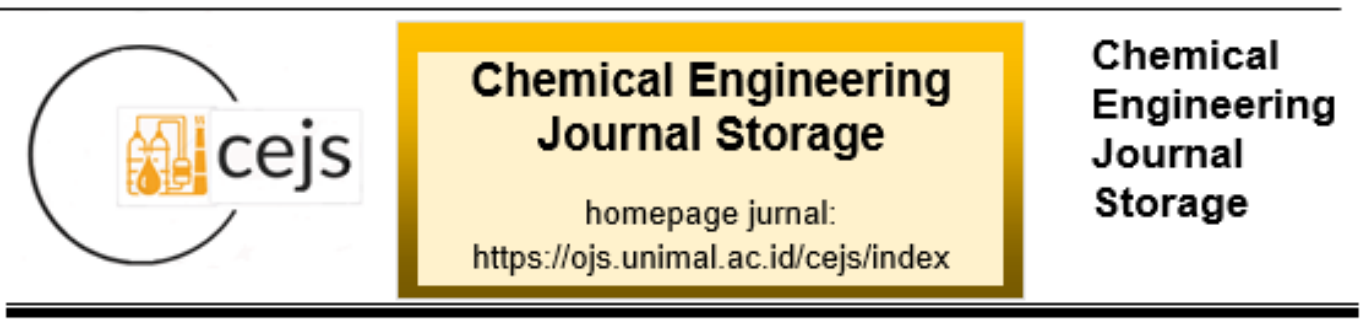

\title{
SINTESIS ESTER SELULOSA STEARAT SEBAGAI WET STRENGTH AGENT UNTUK PAPERBAG DARI TANDAN KOSONG SAWIT (TKS)
}

\author{
Angga Tri Agusna PA, Zainuddin Ginting*, Azhari, Rozanna Dewi, Zulnazri \\ Jurusan Teknik Kimia, Fakultas Teknik, Universitas Malikussaleh \\ Kampus Utama Cot Teungku Nie Reuleut, Muara Batu, Aceh Utara - 24355 \\ Korespondensi: 0811676666, e-mail: zginting@unimal.ac.id
}

\begin{abstract}
Abstrak
Tandan kosong kelapa sawit (TKS) adalah salah satu produk samping (byproduct) berupa padatan dari industri pengolahan kelapa sawit. Kandungan selulosa yang cukup tinggi yaitu sebesar $40 \%$ menjadikan Tandan Kosong Sawit sebagai alternatif lain untuk dimanfaatkan Selulosa sebagai bahan baku pembuatan Ester Selulosa stearat. Ester Selulosa Stearat disintesa melalui reaksi transesterifikasi antara $\alpha$-Selulosa hasil isolasi dari Tandan Kosong Sawit (TKS) dengan metil stearat. Sintesa Metil stearat dilakukan dengan mereaksikan metanol dan asam stearat dengan bantuan katalis $\mathrm{H}_{2} \mathrm{SO}_{4(p)}$. Sintesis Ester selulosa stearat dilakukan dengan cara refluks selama 2 jam menggunakan pelarut metanol dengan variasi katalis $\mathrm{Na}_{2} \mathrm{CO}_{3}$ 5, 10, 15, $20 \mathrm{mg}$ dan dengan variasi volume metil stearat 5, 10, $15 \mathrm{ml}$. Variasi terbaik ditentukan berdasarkan uji derajat substitusi yaitu dengan variasi katalis $\mathrm{Na}_{2} \mathrm{CO}_{3} 20 \mathrm{mg}$ dan volume metil Stearat $15 \mathrm{ml}$, sebesar 1,95. Hasil sintesis yaitu selulosa stearat diuji gugus fungsi dengan spektroskopi FT-IR dan morfologi permukaan menggunakan SEM. Terbentuknya selulosa stearat didukung oleh spektrum FT-IR pada daerah bilangan gelombang 3468,01 $\mathrm{cm}^{-1}$ menunjukkan gugus $\mathrm{O}-\mathrm{H}, 3062,96 \mathrm{~cm}^{-1}$ gugus $C-H$ streching, 1695,43 $\mathrm{cm}^{-1}$ gugus $C=O, 1465,90 \mathrm{~cm}^{-1}$ gugus $C-H$ bending, $1095,57 \mathrm{~cm}^{-1}$ gugus $\mathrm{C}-\mathrm{O}-\mathrm{C}$, dan $609,51 \mathrm{~cm}^{-1}$ gugus $\left(\mathrm{CH}_{2}\right) n>4$. Hasil analisis morfologi permukaan menggunakan SEM menunjukkan bahwa permukaan selulosa stearat tampak homogen, lebih teratur dan memiliki rongga-rongga yang lebih rapat daripada $\alpha$-Selulosa.
\end{abstract}

Kata kunci: $\quad$ Ester Selulosa Stearat,Metil Stearat, Sintesa, Tandan Kosong Sawit

\section{Pendahuluan}

Indonesia merupakan negara penghasil kelapa sawit terbesar di dunia dengan produksi di atas 40,56 juta ton pada tahun 2018. Berdasarkan data Badan Pusat Statistika (BPS) dari publikasi Desember 2019, luas perkebunan kelapa 
sawit di Indonesia mencapai 14,32 juta hektar. Industri pengolahan kelapa sawit ini menghasilkan limbah padat dalam jumlah yang sangat besar seperti Tandan Kelapa Sawit (TKS). Rerata produksi tandan kosong kelapa sawit adalah berkisar $22 \%$ hingga $24 \%$ dari total berat tandan buah segar yang diproses di Pabrik Kelapa Sawit.

Komposisi selulosa yang cukup besar dalam Tandan Kosong Sawit (TKS) menjadikan TKS ini berpotensi untuk dimanfaatkan sebagai bahan baku pembuatan ester selulosa. Bermacam-macam cara telah diperkenalkan membuat ester selulosa ini. Selulosa direaksikan dengan Fatty acid, acyl chloride, Fatty acid vinyl dan fatty acid anhidrid dapat menghasilkan derajat substitusi (DS), (angka DS: 0,3-1,3) tergantung pada rantai cabang asam lemak yang digunakan (Willberg-Keyriläinen and Ropponen 2019).

Berhubung dengan Wet Strength Agent, Wet Strength Agent berfungsi untuk meningkatkan kekuatan fisik kertas ketika terkena air (dalam kondisi basah). kekuatan pada kondisi basah ini sangat diperlukan pada beberapa jenis kertas seperti kertas tissue. Peningkatan kekuatan ini terjadi dengan cara memanipulasi ikatan hidrogen antar serat. maka diperlukan adanya stabilitas kandungan air, sehingga diperlukan suatu ester selulosa terutama dengan angka DS yang besar dan dengan asam lemak rantai Panjang.

Ada beberapa modifikasi selulosa yaitu seperti eterifiksasi (Hong et al. 2013), asetilasi (Çetin et al. 2009), esterifikasi (Spinella et al. 2016) dan transesterifikasi. Transesterifikasi adalah reaksi pembentukan ester dari suatu senyawa ester lain melalui pertukaran gugus alkil dari ester yang bereaksi dengan suatu alkohol. Reaksi transesterifikasi dapat dikatalisis oleh asam maupun basa (Asthasari et al. 2008).

Berdasarkan uraian diatas, peneliti tertarik untuk meneliti lebih lanjut tentang selulosa dari Tandan Kosong Sawit (TKS) yang berpotensi untuk dimodifikasi melalui reaksi transesterifikasi dengan metil Ester Stearat, sehingga selulosa memiliki sifat yang lebih baik. 


\section{Bahan dan Metode}

Bahan dan peralatan yang diperlukan dalam penelitian ini adalah Tandan kosong kelapa sawit (TKS) dari PT. Ika Bina Agro Wisesa, Aquadest, $\mathrm{HNO}_{3}$ $3,5 \%, \mathrm{NaOH} 2 \%, \mathrm{Na}_{2} \mathrm{CO}_{3}, \mathrm{Na}_{2} \mathrm{SO}_{4}, \mathrm{NaOH} 17,5 \%, \mathrm{Na}_{2} \mathrm{SO}_{3} 2 \%, \mathrm{NaOCl} 1,75 \%$, $\mathrm{H}_{2} \mathrm{O}_{2}$, Asam Stearat, n-heksan, Indikator Phenoftalein, $\mathrm{KOH} 0.5 \mathrm{M}, \mathrm{HCl} 0.5 \mathrm{M}$, Etanol 75\% dan Metanol.

Penelitian ini terdiri dari delapan tahap yaitu Isolasi Selulosa dari Tandan Kosong Kelapa Sawit, Pembuatan Metil Stearat, Sintesis Ester Selulosa Stearat, Penentuan Derajat Substitusi (Wurzburg 1978 dalam Singh 2004), Preparasi Sampel, Isolasi $\alpha$-selulosa dari Tandan Kosong Kelapa Sawit, Pembuatan Metil Stearat dan Pembuatan Ester Selulosa Stearat. Variasi percobaan dilakukan terhadap massa katalis yang digunakan serta volume metil stearat. Isolasi $\alpha$ Selulosa yang digunakan pada penelitian ini adalah hasil isolasi dari tandan kosong kelapa sawit. $\alpha$-selulosa yang diperoleh dari $75 \mathrm{~g}$ hasil isolasi Tandan Kosong Sawit sebanyak 16, 51 gram (22,01\% dari berat awal).

Pembuatan Metil Stearat dilakukan dengan reaksi esterifikasi antara Asam Stearat yang digunakan berasal dari PT. SOCIMAS dengan Metanol

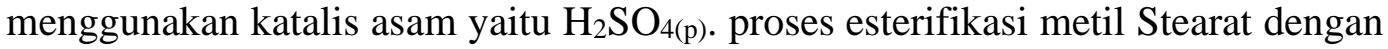
direfluks pada suhu $70-80^{\circ} \mathrm{C}$ selama 2 jam. Diperoleh metil Stearat berwarna bening. Selulosa Stearat diperoleh dengan mereaksikan $\alpha$-selulosa dari Tandan Kosong Sawit dengan metil Stearat dengan menggunakan katalis $\mathrm{Na}_{2} \mathrm{SO}_{3}$ dan pelarut metanol. Pada penelitian ini juga menggunakan $1 \mathrm{~g}$ selulosa dan dilakukan variasi volume metil stearat dan katalis. Dimana variasi volume metil stearat yakni 10,20, dan 30, sedangkan variasi katalis berturut - turut 5, 10, 15, 20 gram. hasil sintesis yang diperoleh dilakukan uji derajat substitusi untuk menentukan suhu terbaik dan katalis, Analisis Spektrofotometer FT-IR $\alpha$-Selulosa dan Analisa Morfologi Permukaan dengan SEM (Scanning Electron Microscopic). 


\section{Hasil dan Diskusi}

\subsection{Isolasi $\alpha$-selulosa dari Tandan Kosong Sawit}

a-Selulosa yang digunakan pada penelitian ini adalah hasil isolasi dari tandan kosong sawit yang berasal dari pabrik PKS PT. Ika Bina Agro Wisesa (IBAS). Selulosa yang dianalisis dari hasil isolasi Serat tandan kosong sawit sebanyak 75 gram melalui beberapa tahap sesuai metode penelitian sebelumnya. $\alpha$-selulosa yang diperoleh dari $75 \mathrm{~g}$ hasil isolasi Tandan Kosong Sawit sebanyak 16,51 gram (22,01\% dari berat awal).

Pada penelitian ini, proses delignifikasi dilakukan menggunakan larutan $\mathrm{NaOH} 2 \%$ pada suhu $50^{\circ} \mathrm{C}$ sehingga lignin dapat larut. Terlarutnya lignin pada temperatur tersebut disebabkan karena molekul lignin terdegradasi oleh nukleofil basa kuat $\left(\mathrm{OH}^{-}\right)$.

Pada proses delignifikasi dihasilkan selulosa berwarna kuning sehingga perlu dilakukan proses pemutihan (bleaching). Proses pemutihan (bleaching) bertujuan untuk menghilangkan sisa-sisa lignin yang masih menempel. Pada proses ini digunakan $\mathrm{NaOCl}$ sebagai reagen pemutih. Pada proses pemutihan akan dihasilkan selulosa berwarna putih namun selulosa tersebut masih terdiri dari $\alpha, \beta$, dan $\gamma$-Selulosa. Oleh karena itu, perlu dilakukan pemisahan $\alpha$-Selulosa dari $\beta$ dan $\gamma$-Selulosa dengan menggunakan $\mathrm{NaOH} 17,5 \%$, dimana $\alpha$-Selulosa akan mengendap sedangkan $\beta$ dan $\gamma$-Selulosa akan larut (Nativel and Impr. LEN) 2015). Hasil yang diperoleh berupa $\alpha$-selulosa yang masih berwarna kuning sehingga perlu dilakukan pemucatan dengan $\mathrm{H}_{2} \mathrm{O}_{2} \quad 10 \%$ untuk menghilangkan pigmen yang melekat pada selulosa. Kemudian dikeringkan untuk mengurangi kadar air, Sehingga diperoleh $\alpha$-Selulosa berwarna putih. Hasil Isolasi $\alpha$-Selulosa kemudian Dianalisa menggunakan Uji gugus fungsi (FT-IR) dan Uji Morfologi (SEM). 


\subsection{Hasil Analisis Spektrofotometer FT-IR pada $\alpha$-Selulosa TKS}

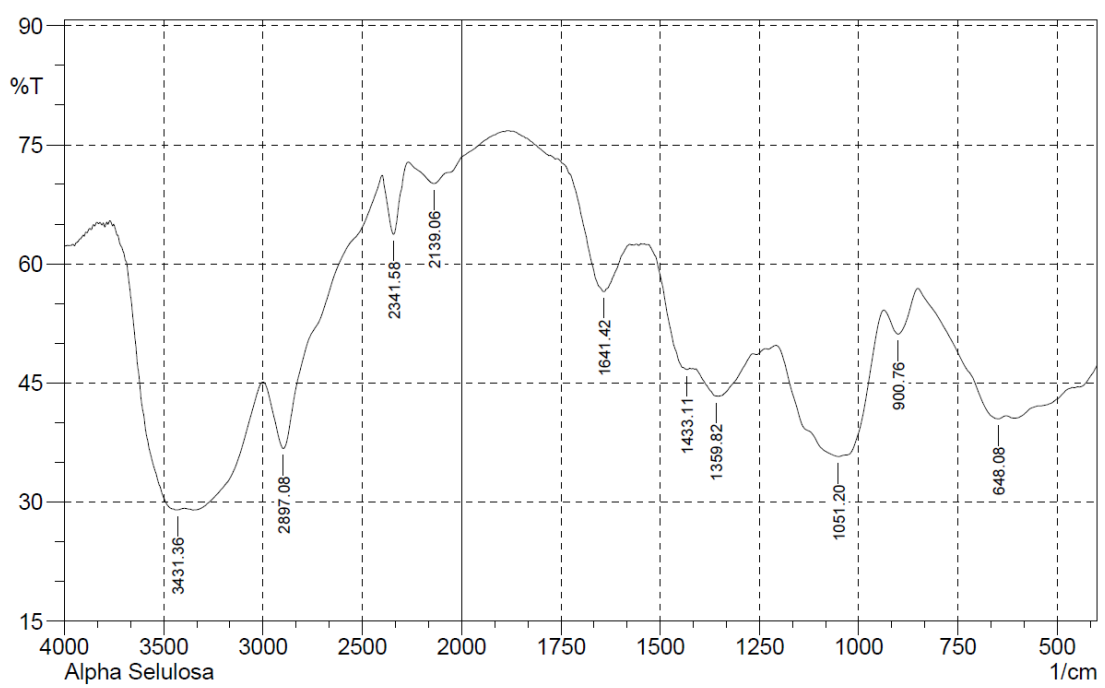

Gambar 1 Spektrum FT-IR $\alpha$ - Selulosa dari Tandan Kosong Sawit

Dari data spektroskopi FT-IR $\boldsymbol{\alpha}$-selulosa dari Tandan Kosong Sawit (TKS) memberikan spektrum dengan puncak-puncak vibrasi pada daerah bilangan gelombang $3431.36 \mathrm{~cm}^{-1}$ yang menunjukkan gugus $-\mathrm{OH}, 2893,22 \mathrm{~cm}^{-1}$ yang menunjukkan gugus C-H sretching; $1359,82 \mathrm{~cm}^{-1}$ yang menunjukkan gugus $\mathrm{C}-\mathrm{H}$.

\subsection{Hasil Analisa Morfologi Permukaan SEM pada $\alpha$-selulosa TKS}




Gambar 2 Hasil SEM dari $\alpha$-selulosa TKS (a) Perbesaran 1000x (b) perbesaran $2000 x$

Analisa morfologi permukaan SEM (Scanning Electron Microscopic) dilakukan untuk melihat morfologi permukaan hasil isolasi $\alpha$-Selulosa dari Tandan Kosong Sawit (TKS). Analisa ini akan menunjukkan gambaran seberapa baik interaksi reagensia yang digunakan dalam modifikasi selulosa. Dalam penelitian ini analisa morfologi permukaan SEM dapat dilihat pada Gambar 4.4 dengan perbesaran 1000 kali dan 2000 kali. Adapun hasil SEM dari $\alpha$-selulosa hasil isolasi dari Tandan Kosong Sawit (TKS) menunjukkan morfologi permukaan yang tampak homogen dan halus.

\subsection{Hasil Analisis Spektrofotometer FT-IR pada Ester Selulosa Stearat}

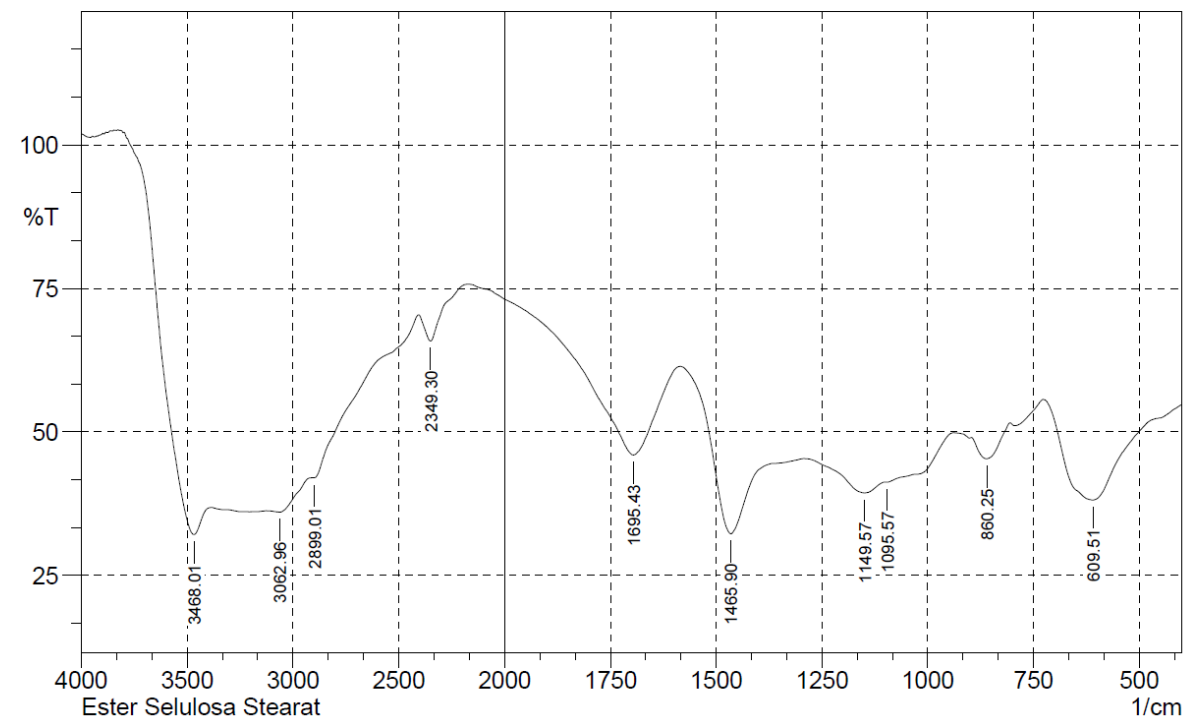

Gambar 3. Spektrum FT-IR Ester Selulosa Stearat

Dari data spektroskopi FT-IR Ester Selulosa Stearat memberikan spektrum dengan puncak-puncak vibrasi pada daerah bilangan gelombang 3468,01 $\mathrm{cm}^{-1}$ yang menunjukkan gugus - $\mathrm{OH}, 3062,96 \mathrm{~cm}^{-1}$ yang menunjukkan gugus $\mathrm{C}-\mathrm{H}$ stertching, $1695,43 \mathrm{~cm}^{-1}$ yang menunjukkan gugus $\mathrm{C}=\mathrm{O}, 1465,90 \mathrm{~cm}^{-1}$ menunjukkan gugus $\mathrm{C}-\mathrm{H}$ bending, $1095,57 \mathrm{~cm}^{-1}$ yang menunjukkan gugus C-O$\mathrm{C}$, bilangan gelombang $609,51 \mathrm{~cm}^{-1}$ menunjukkan gugus $\left(\mathrm{CH}_{2}\right) \mathrm{n}>4$.

Pada Gambar 4 menunjukan perbandingan spektrum FT-IR $\alpha$-Selulosa dan 
Ester Selulosa Stearat.

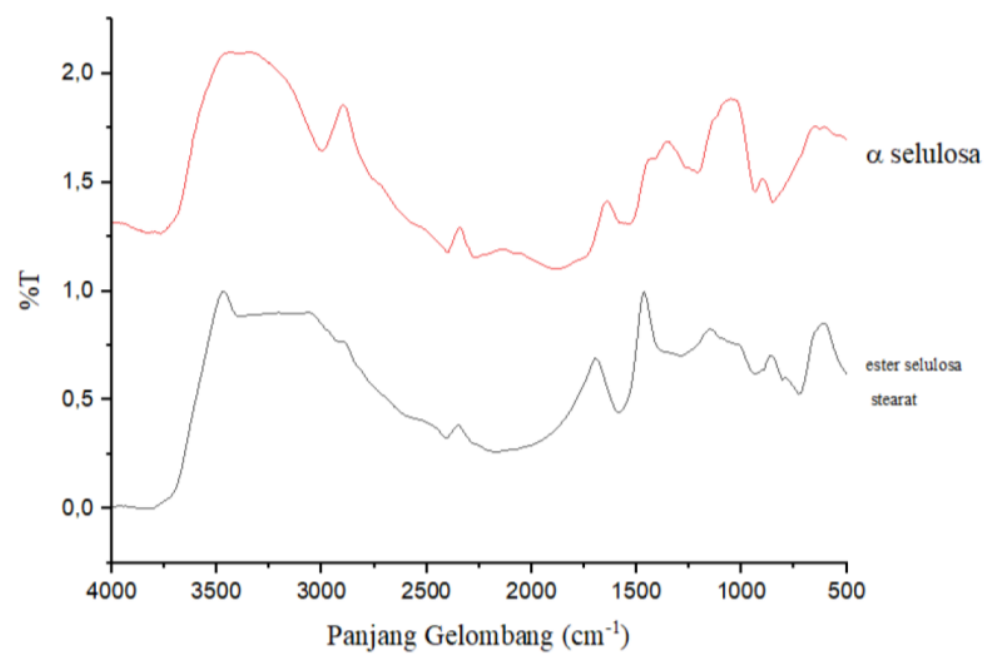

Gambar 4 Perbandingan Spektrum FT-IR Selulosa dan Selulosa Stearat

\subsection{Hasil Analisa Morfologi Permukaan SEM pada Ester Selulosa Stearat}

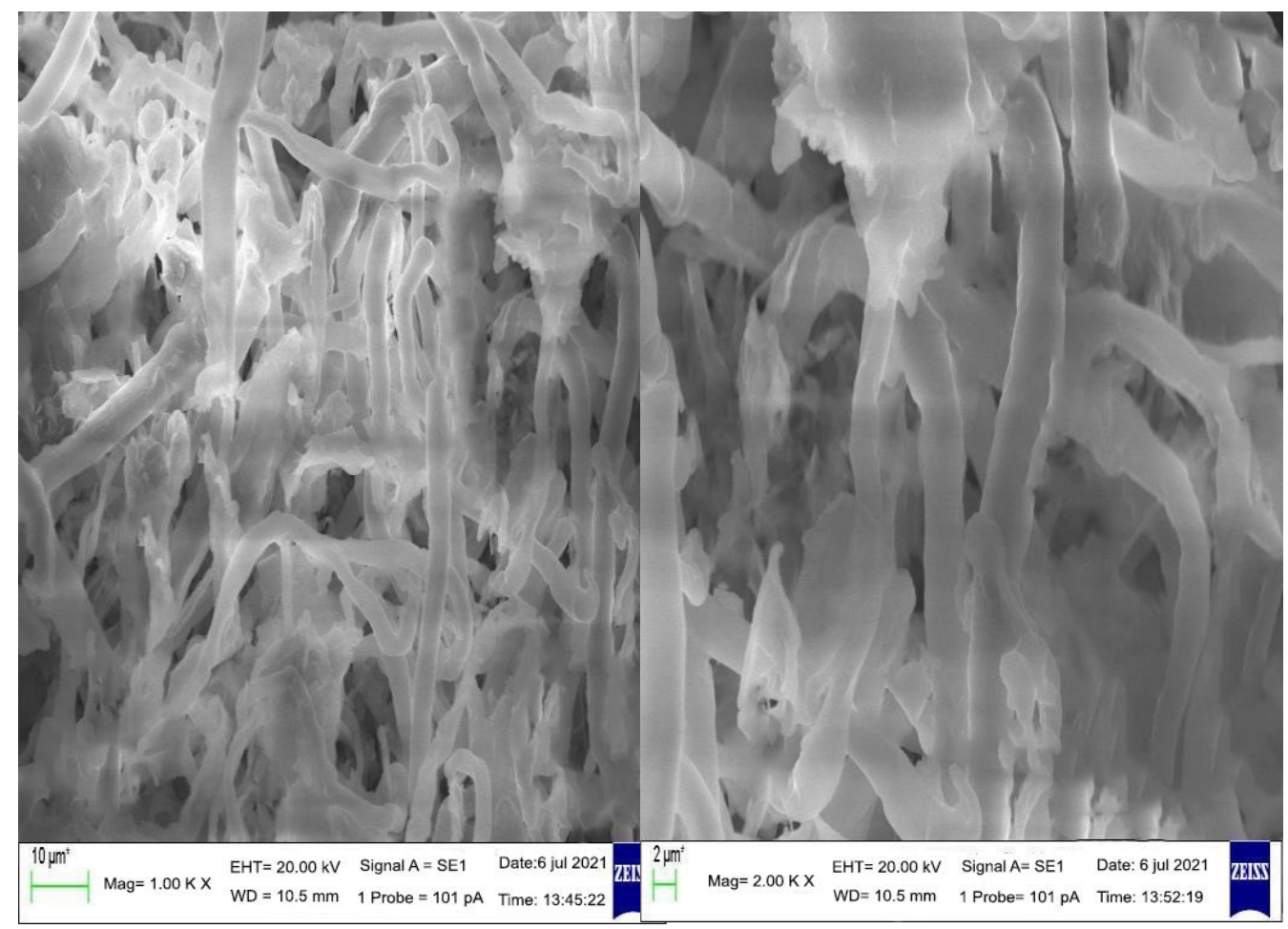

Gambar 5 Hasil SEM dari ester selulosa stearat (a) Perbesaran 1000x (b) perbesaran $2000 x$ 
Analisa morfologi permukaan SEM (Scanning Electron Microscopic) dilakukan untuk melihat morfologi permukaan Ester Selulosa Stearat. Dalam penelitian ini analisa morfologi permukaan SEM dilakukan pada sampel 12 yang memiliki DS sebesar 1,95 dan dapat dilihat pada Gambar 4.5 telah terjadi perubahan morfologi permukaan yang menandakan bahwa telah terjadi reaksi antara gugus $\mathrm{OH}$ pada atom $\mathrm{C} 2$ selulosa dengan gugus karbonil dari metil Stearat. Permukaan pada perbesaran 1000 dan 2000 kali tampak homogen, lebih teratur dan memilki pori-pori yang lebih besar daripada $\alpha$-selulosa sebelum di Esterifikasi.

\subsection{Pengaruh katalis $\mathrm{Na}_{2} \mathrm{CO}_{3}$ dan Metil Stearat terhadap Derajat Substitusi} (DS)

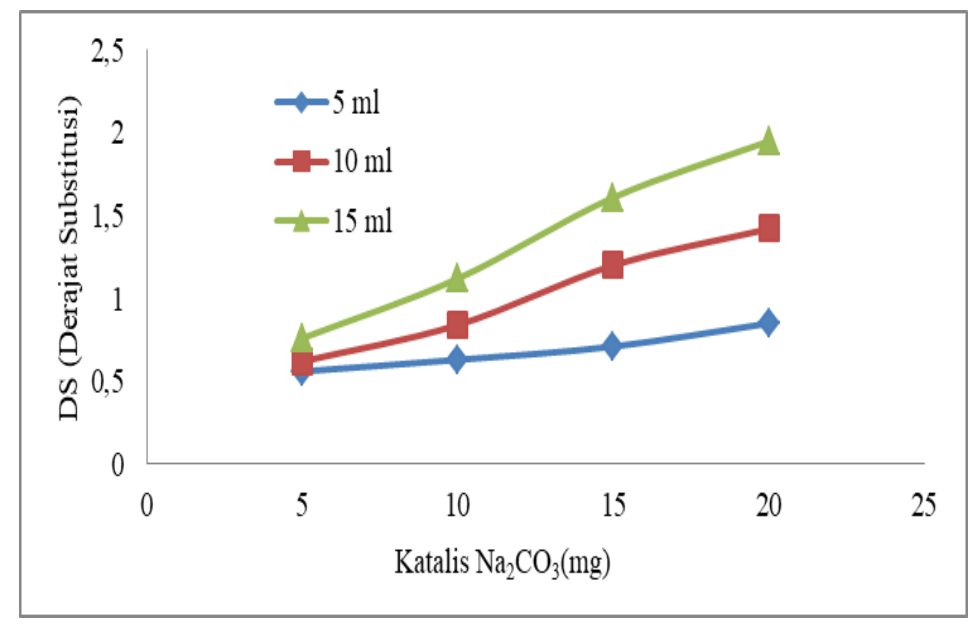

Gambar 6. Pengaruh katalis $\mathrm{Na}_{2} \mathrm{CO}_{3}$ dan Metil Stearat terhadap Derajat Substitusi (DS).

Hasil penelitian Derajat Substitusi yang ditentukan secara titrasi dengan sampel ditambahkan dengan $40 \mathrm{ml} \mathrm{KOH}$ 0,5 M. Kelebihan alkali kemudian dititrasi dengan $\mathrm{HCl}$ 0,5 M menggunakan indikator PP. Derajat Subsitusi adalah jumlah rata-rata gugus per anhidroglukosa yang disubstitusikan oleh gugus lain. Apabila gugus yang menggantikan berupa satu gugus anhidroksil pada tiap unit anhidroglukosa diesterifikasi dengan satu gugus asetil, nilai DS Sebesar 1. Apabila terdapat tiga buah gugus hidroksil yang diesterifikasi, maka nilai DS sebesar 3 (Das 2015). 
Pada Gambar 6 dapat dilihat pengaruh penambahan metil stearat berbanding lurus dengan nilai Derajat Subsitusi semakin banyak penambahan Volume Metil Stearat maka nilai DS semakin tinggi. Pada Pengaruh katalis $\mathrm{Na}_{2} \mathrm{CO}_{3}$ juga nilai DS berbanding lurus dalam artian semakin banyak katalis yang digunakan maka nilai DS yang diperoleh semakin besar. Nilai DS terbaik terdapat pada variasi katalis $\mathrm{Na}_{2} \mathrm{CO}_{3} 20 \mathrm{mg}$ dan volume metil Stearat $15 \mathrm{ml}$ dengan nilai DS sebesar 1,95. Hal ini menunjukkan banyaknya gugus ester yang tersubstitusi ke gugus $\mathrm{OH}$ pada $\alpha$-selulosa sebesar 1,95. Dapat disimpulkan pada penelitian ini yaitu semakin besar nilai derajat substitusi memunginkan semakin banyaknya gugus yang tersubstitusi.

\section{Simpulan}

Ester Selulosa stearat merupakan hasil sintesis antara $\alpha$-selulosa dengan hasil metil stearat dengan bantuan katalis $\mathrm{Na}_{2} \mathrm{CO}_{3}$ sehingga menghasilkan Ester Selulosa stearat. Karakterisasi dari selulosa stearat yaitu berdasarkan analisis FTIR didapat puncak vibrasi pada daerah bilangan gelombang $3468,01 \mathrm{~cm}^{-1}$ menunjukkan gugus $\mathrm{O}-\mathrm{H}, 3062,96 \mathrm{~cm}^{-1}$ menunjukkan gugus $\mathrm{C}-\mathrm{H}$ streching, $1695,43 \mathrm{~cm}^{-1}$ menunjukkan gugus $\mathrm{C}=\mathrm{O}, 1465,90 \mathrm{~cm}^{-1}$ menunjukkan gugus $\mathrm{C}-\mathrm{H}$ bending, 1095,57 $\mathrm{cm}^{-1}$ menunjukkan gugus C-O-C, $609,51 \mathrm{~cm}^{-1}$ menunjukkan gugus $\left(\mathrm{CH}_{2}\right) \mathrm{n}>4$. Berdasarkan hasil SEM permukaan pada perbesaran 1000 kali, dan 2000 kali pada Ester Selulosa Stearat tampak lebih homogen, lebih teratur dan memiliki rongga-rongga yang lebih rapat daripada $\alpha$-selulosa sebelum di Esterifikasi.

\section{Daftar Pustaka}

1. Asthasari, RU, Departemen Teknologi, Industri Pertanian, and Fakultas Teknologi Pertanian. 2008. "Kajian Proses Pembuatan Biodiesel Dari Minyak." Skripsi.

2. Çetin, Nihat Sami, Philippe Tingaut, Nilgül Özmen, Nathan Henry, David Harper, Mark Dadmun, and Gilles Sèbe. 2009. "Acetylation of Cellulose Nanowhiskers with Vinyl Acetate under Moderate Conditions." Macromolecular Bioscience 9(10):997-1003. 
3. Das, Satyajit. 2015. "Book Reviews: Book Reviews." Wilmott 2015(80):62-69.

4. Hong, Jingjun, Hanqiao Feng, Zheng Zhou, Rodolfo Ghirlando, and Yawen Bai. 2013. "Identification of Functionally Conserved Regions in the Structure of the Chaperone/CenH3/H4 Complex." Journal of Molecular Biology 425(3):536-45.

5. Nativel, Claude. and Impr. LEN). 2015. "Comme Le Phénix : Roman."

6. Spinella, Stephen, Anthony Maiorana, Qian Qian, Nathan J. Dawson, Victoria Hepworth, Scott A. McCallum, Manoj Ganesh, Kenneth D. Singer, and Richard A. Gross. 2016. "Concurrent Cellulose Hydrolysis and Esterification to Prepare a Surface-Modified Cellulose Nanocrystal Decorated with Carboxylic Acid Moieties." ACS Sustainable Chemistry and Engineering 4(3):1538-50.

7. Willberg-Keyriläinen, Pia and Jarmo Ropponen. 2019. "Evaluation of Esterification Routes for Long Chain Cellulose Esters.” Heliyon 5(11). 